\title{
Self-Strengthening Movement of Late Qing China: an Intermediate Reform Doomed to Failure
}

\author{
Jason $\mathrm{Qu}^{1}$ \\ ${ }^{1}$ International St. George's School in Vancouver, British Columbia, Canada \\ Correspondence: Jason Qu, International St. George's School in Vancouver, British Columbia, Canada. E-mail: \\ aaronzhang8584@163.com
}

Received: July 1, 2016

Accepted: July 19, 2016

Online Published: August 25, 2016

doi:10.5539/ach.v8n2p148

URL: http://dx.doi.org/10.5539/ach.v8n2p148

\begin{abstract}
Despite of strong economy including highest GDP gross and self-sufficient feudal economy system, the late Qing Empire fell behind the world trend with its isolationist trade policies. As the Western world caught up technologically, economically, and politically, the former biggest economy had suffered from consecutive losses in wars. In order to preserve the feudal regime, the initiative reform, termed the Self Strengthening Movement was grandly carried out. However, without the true support from the supreme power on one hand, and without the support of the populace on the other, the Movement was an intermediate reform in attempt to preserve the royal system and forestall its continued decline. In policy, the reforms envisioned Western-style modernization without adjusting the political order, yet the entrenched conservatism of the Qing Imperial Court proved to be the decisive hindering factor in the failure of the Movement.
\end{abstract}

Keywords: Self-strengthening Movement, intermediate reform, late Qing Dynasty, modernization

\section{Historical Context}

The last Chinese Imperial Dynasty of the Qing ruled from the mid- $17^{\text {th }}$ century to the early $20^{\text {th }}$ century. Issues traditionally central around Chinese society, such as overpopulation, famine, bureaucratic corruption and inefficiency, took a greater toll on the Qing State and the Chinese nation than ever before. This, coupled with ethnic dissent between the ruling Manchus and the indigenous Han Chinese, would further intensify China's societal issues in a way never seen before. Furthermore, popular sentiment against foreign aggression also expressed itself in the Boxer Rebellion, signifying anti-imperialist and anti-western feelings. The staunchly conservative Qing court did not help China's woes: as foreign imperialist powers began to encroach on Chinese territory with their own interests in mind, China found its aging technologies and society unable to cope with this pressure. Thus, Qing China reflected a development of new socio-economic and ethnic tensions to a level never seen before.

Throughout most of the Chinese history, China was an economic, cultural, and political leader. It produced goods in the form of porcelain, silk, and spices which were traded around the world. Its empire demanded tribute and subordination from neighbouring kingdoms and polities, and extended a sphere of influence throughout East Asia and even Europe through the spread of Chinese goods and ideologies in the region.

During the period of the Qing Dynasty, China was no doubt a super economy. From 1700 to 1820, the GDP of China ranked the first in the world with its portion in global economy growing from $22.3 \%$ to $32.9 \%$. Chinese self-sufficient economic system featured strong stability, which laid solid economic foundation for the "seclusion policy". On one hand, the Qing court took so great pride of its economic performance that authorities regarded foreign countries as "barbaric" and became intoxicated in "the only civilization under heaven", and denied the fact that the world used to be under its dominance was undergoing tremendous changes (Sun, 2011). On the other hand, many western countries had broken the restraint of feudalism and entered the era of capitalism. Once capitalistic economy was admitted into China, the feudal natural economy would be disorganized, and thus shake the very foundation of the Qing Empire. In order for the protection of self-sufficient economy as well as national defense, the Qing rulers implemented the policy which stopped all foreign contact, hindering China's modern progress with lockstep. 
However, neither GDP gross nor GDP ranking in the world could provide a comprehensive reflection of the level of economic development or the international standing of a state. As the Western world caught up technologically, economically, and politically, this ancient world order that China had basked in for millennia was slowly collapsing, replaced by a new, Western-led imperialist order. The industrial revolution in Europe yielded great technological advances for the West, and resulted in more effective systems of communication, transportation, war mongering and a greater thirst for resources. As Western nations and westernizing nations including Japan began to pursue more zealously the resources and material riches of East Asia, China found itself at the center of colonial desire. The West, eager to enter the lucrative Chinese market, petitioned China for an opportunity to engage in mutual trade.

However, as China denied the West this opportunity, tensions built up, culminating in the Opium Wars, where the technological disparity between China and the West was unmistakably exposed. Since 1840, the former biggest economy had suffered from consecutive losses in wars. What the Qing Empire had gradually lost was not only its territory but also the international status. In any case, the late Qing China was by no means a strong entity, but a weak, semi-colonial country that frequently ceded territory and paid indemnities.

Slowly, as $t$ the façade of Chinese superiority began to crumble away, China found itself out of touch with the modern world. It no longer knew how to interact with the outside world, nor did it comprehend its position within it.

This new position of China in the world elicited a concerned response from the Qing court. Certain court factions denied the existence of Chinese backwardness, instead resorting to traditionalism and conservative Chinese thought as methods of preserving Qing control over China. However, other court factions saw reform as essential in maintaining China's control over its own affairs. Liberal-minded court factions unanimously agreed that reform was crucial in preventing the collapse of the Qing polity; the nature of this reform, however, was widely disputed. Some saw reform as a mere introduction of Western technologies and their application to the Chinese military in the form of guns, artillery, steel naval ships, and modern infantries to strengthen China's military force and fend off foreign imperialist interests. Others envisioned a grander plan of introducing Western industrial practices and instituting many Western material characteristics, such as railways, postage systems, or roads in Chinese society. A few radicals even pushed for modern westernization of the education system from traditional Confucian studies and an abandonment of the 2000 -year-old absolute monarchical system in favour of a constitutional monarchy. However, dissent, reactionary forces, and a lack of an organized initiative limited the grand plans of reform from ever becoming reality. The failure of this initiative, termed the Self Strengthening Movement and the Hundred Day's Reform, ultimately dictated the future of the Qing as a state and the fate of China as a nation.

\section{Historiography}

A variety of historical narratives exist, critically analyzing the Self-Strengthening Movement and its effects. Certain perspectives regard disunity amongst the reformers and fierce conservative opposition as being the main factors hampering the success of the movement. Others take into account traditional Chinese statecraft and philosophies when analyzing the demise of the reforms. In a lesser-known epistemological analysis of the movement, doubt has been cast on the very nature of the movement and the influence of this view on later appraisals of the movement and its success. Still other theories see the Qing as doomed to fail and the Self-Strengthening Movement as merely another manifestation of its corruption and institutional inefficiencies.

Scholars such as Li Chien Nung, Samuel Chu, and Benjamin Elman are representatives of those advocating historiographical theories which lambast conservative opposition, disunited reform policies, and institutional corruption in causing both the failure of the Self-Strengthening Movement and the demise of the Qing. According to Chu (1965), for instance, "China suffered from a lack of unified leadership working toward reform and modernization...[whereas] the vast majority of the ruling official-gentry class was conservative in outlook and regarded innovations as possible threats to the basis upon which its privileged position in Chinese society was founded." Additionally, they also champion the view that the disorderly, regionalist, and factional structure of the Qing court and administration, as well as corrupt officials, made it hard to channel the resources for both reform and military efforts against foreign aggressors. Further, Elman (2004) states, "lack of leadership, vested interests, (and) lack of funding contributed to the inadequacies of the late Qing state. Finally, they hold that the indecisive and indeterminate plans and policy of the court rendered the Qing state and China vulnerable to foreign military advances. $\mathrm{Li}$, Chu, and Elman believe that a lack of firm leadership in both reform activities and normal functions of state was the most characteristic features of this period of Chinese history. 
Other academics such as Michael Gasster (1972) and Kwang-Ching Liu, however, have claimed that the failure of the Self-strengthening Movement was due to the intrinsic flaws in the philosophy of the movement. They do not downplay the flaws of the Qing polity, nor do they reject the lack of consistency in the reform movement as a factor. However, they see the reforms as a defense mechanism, as a method for preserving the Chinese world order that had existed for over two millennia against the new encroaching imperialism of the West. Gasster notes, "All that they did [Western education, technology, diplomacy, etc.], however, they considered means of defense. Each step had to be justified on the grounds that it would help to keep the foreigners out; at the same time, each experiment had to be guaranteed not to impinge on the essentials of Chinese life." Yet, the reforms, if too radical, would never have gained any momentum from the Qing establishment.

Luke S. K. Kwong (1984) argues that the Self-Strengthening Movement itself never actually failed. Kwong believes that since the Movement was appraised as a military movement, later generations have seen the reforms as a failure due to the military losses near the end of the Dynasty. However, if the reforms were seen merely as an adaptive strategy to reform the nation, it can be argued that ideas and technologies from the West were imported and spread throughout China through trade, the various academies set up by the reformists, and by the students sent abroad to study western academic subjects. Thus, a flawed interpretation of the movements by academics created the illusion of the failure of the Self-Strengthening Movement.

From the historiographical analysis, two main groups emerge, those focusing on the political struggles of the Qing imperial administration and those focusing on the philosophy behind the reforms. Both narratives are based on an underlying question - was the Qing destined to be vanquished by a new world order set up by imperialist minded Western states, or did the Qing's internal issues prove to be conducive to its demise?

\section{The Nature of the Reform Movement}

By the mid- $19^{\text {th }}$ century, China began to see its millennia-old illusions of superiority slowly erode away. Its world order, consisting of the tribute system, the Mandate of Heaven, and the isolationist trade policies, began to seem irrelevant and obsolete. As the West began to exert its force and influence over the Qing Empire, scholars and officials within the Empire would see a need to emulate the technologies, organizational hierarchies, and cultural traditions of the Occident in an attempt to prevent China from becoming subjugated by the will of Western Imperialism. This process of endeavoured reform and emulation became known as the "Self-Strengthening Movement".

In terms of scope, the reforms envisioned Western-style modernization in a variety of fields: military and industrial technology, intellectual and academic thoughts, reorganization of the military organizational and diplomatic system, economic restructuring, and more. Reforms as radical as adjusting the political order were also proposed.

However, in reality, the reforms were mainly limited to material matters, such as the improvement of weaponry and transportation infrastructure, with few instances of actual intellectual and institutional reform. It was thought that modern materials such as steamships, guns, and cannons would help provide the Qing with the physical force necessary to repel foreign troops. The Qing establishment believed there was no need for any alterations to be done to social and academic institutions; in fact, once any reform activity began to threaten a traditional Chinese practice or philosophy that activity was promptly terminated, treated as an attempt gone wrong.

Yet perhaps the scope of the reform movement may not have been as limited as previously thought. With the massive amounts of conservative opposition to the reforms, it may have been good judgement and prudence that restricted reform activities to simply technological affairs. Considering the strong repudiation of Western-style schools and education by the court in the 1860's and 1870's, pursuing more wide-ranging reforms in education, politics, the military, and the economy with a comparable zeal may have simply been foolish. Despite the Qing government's choice to limit the scope of its reforms, the fact that such reforms were even realized in the first place implies that China had begun to take its first steps towards modernizing and adapting to the new world order. Thus, activities of reformers such as Li-Hung Chang, Tseng-Kuo-fan, and Tso Tsung-t'ang in initiating reform activities such as the Fuchow artillery, Fukien Shipyard, and Peiyang Navy, rather than being in vain, may have helped sow the seeds for Western-style modernization in the Republican period after the demise of the Qing in 1911.

A quick analysis of events lends some comparative insight into the efforts and achievements of the Chinese Self-Strengthening Movement. The Movement itself was as a haphazard attempt to preserve the Qing Empire and forestall its continued decline. Through this, China could preserve its traditions and institutions by fending off Western encroachment into its territories, politics, and economics. Its sole purpose, for most scholars and officials, was to protect and shield the old systems of tribute, isolationism, and Sino-centrism in a rapidly evolving and changing world dictated not by China's terms but by the Occidental powers (Gasster, 1972). Yet, 
the Self-Strengthening Movement neglected to consider the possibility that China had to change with the world, rather than the world with China.

\section{Causes and Effects of Manchu Conservatism On the Reform Movement}

\subsection{Ethnic Dynamics and Effects on Governing Ideologies}

The Qing dynasty was one of two dynasties in Chinese imperial history ruled by a non-Han Chinese people. The Aisin-Gioro clan, the imperial family of the Qing, and its Manchu nobility constituted a minority within the Chinese population. Consequently, in order to justify its rule over a large Han majority population, the Qing adhered to strict Confucian policies and methods of governance as a measure of legitimacy, a method aimed at gaining support from the indigenous Han. This tactic proved successful in co-opting the Han gentry and contributing to a continuation of Chinese-style institutions and ways of thought.

After the Manchu entered Central China and established the Qing regime, most of traditional Chinese culture was adopted by the Aisin-Gioro clan as a basis for its administration. The contributions of Manchu were especially manifested in the safeguard of "the big unification" that all previous dynasties had maintained and the promotion of such identity among all ethnic groups including the Han group. While advocating harmony between Han and Manchu, early Qing emperors, including Emperor Kangxi, Emperor Yongzheng and Emperor Qianlong, showed their initiatives in absorbing traditional Chinese culture, and resolved effectively the resistance of the Han people towards the Qing regime. The legal status of the Manchu ruling class was finally recognized by the Han intellectuals. Gradually, the Han group showed great obedience to and submitted themselves to the Manchu ruling class.

Traditional Chinese conservative thought, embodied in Confucian principles, values Chinese ways of life over foreign ones. It regards the customs of foreign people as inherently inferior and commonly ascribes to them the moniker of being "barbaric." This ethnocentric view of the world and of China's relation to it manifested itself in many Chinese imperial traditions and institutions, such as the tribute system and the imperial examination system, traditions in which the Han took great pride. The Manchu dynasty used such pride to its advantage, and in propagating a sense of Chinese greatness and superiority in tradition, established its legitimacy as a protector of China's heritage and supremacy. However, as the West rose to prominence and began to make its mark on the world, this mindset would make it problematic and inherently illogical for China to adapt to a world dominated by Western imperialism.

\subsection{Reasons for Opposition}

The Self-Strengthening movement itself recognized the weaknesses of China's technological and intellectual capital. As evidenced in a memorial to the throne from Li Hung-chang in 1872, reformists believed that technological disparities between China and the West were a major vulnerability in China's dealings with the West. Reformists saw value in not only bringing Western-style military hardware to China, but also in pursuing educational reform and Western studies. As evidenced from a letter from the Chinese Minister to England and France Kuo Sung-tao to Li Hung-chang, an adoption of foreign studies was crucial to China's attempt at Westernizing.

Yet, the deeply entrenched conservative atmosphere of the Manchu court made such thought sacrilege, a betrayal of traditional Chinese philosophies and technologies. Conservative court officials even believed that Western learning would produce within Chinese scholars an affinity for the West, and result in disastrous effects for the Qing. In a memorial to the throne submitted by Wo-jen, Grand Secretary and head of the Hanlin Academy (Imperial Institute), Western studies and pedagogues were seen as useless and ultimately debilitating to Qing power.

\subsection{Effects of Conservatism on the Self-Strengthening Movement}

The Self-Strengthening Movement was never an official policy or directive of the Qing court; rather, it was a loose collection of activities and objectives pursued by reform-minded officials. Without a unified movement under which reformists could rally or a central court backing to fortify the image of the Movement, the reformists and the Self-strengthening Movement were vulnerable to critique and a barrage of opposition from conservative court officials. The Movement's supporters were outnumbered and overcome by its opponents, and such a situation would hinder the Movement's momentum.

Xenophobia coupled with restrictions on Western learning also contributed to a misunderstanding of, and subsequently, an ignorance of the West by court officials. Court suspicion of reforms and reformists was a key result of such a mindset, one that would persuade the court in closing down artilleries, schools, and factories and dissuade the populace from participating in activities associated with the West. 
A conservative body of scholar-officials and their support from the Imperial court would prove to be the main hindrance to the success of the Self-strengthening Movement. Their writings, arguments, and actions would ultimately undermine the activities of reformists during the period from 1863 to 1895 .

\section{Lack of Unity within the Reform Movement}

\subsection{A Collection of Dispersed Regional Activities - Lack of a Unified Vision}

When one mentions the 1863-1895 reform movement, names such as Li-Hung-chang, Tseng Kuo-fan, and Tso Tsung-t'ang emerge as leaders of the Self-strengthening Movement. Indeed, such individuals were prominent proponents of reform activities and did produce results in their respective efforts. However, while they may have conversed with each other about the Movement and even collaborated on reform activities on certain occasions, they and other reformists never created an official reform policy complete with a list of guidelines and goals that could be applied to the whole state, nor were they ever unified in their attempts at reforms. Rather, their endeavours were individual and were never part of any grand vision for a reconstructed China.

The absence of a unified and coordinated reform policy was suddenly revealed to the Qing court and all its officials when China's reforms were put to the test in the First Sino-Japanese War. The Peiyang fleet, a product of China's Self-strengthening era through the mid to late 1800's and the flagship fleet of the Chinese Navy, was sent to confront the newly Westernized Japanese Imperial Navy in battle. Yet a lack of cooperation and cohesion within the Qing in dealing with the war effort led to China's defeat and the loss of the entirety of the Peiyang fleet - which was much more powerful than its Japanese rival in both the size and equipment, yet much inferior in terms of administration - through either destruction or surrender to the Japanese forces.

Dispersed reform-minded undertakings could not produce the wide-sweeping and broad changes of the Qing system that reformists had intended; they could only create results which were transient in nature with superficial effects. Thus, the Qing gradually saw its efforts come to nothing and its vision of a strong and powerful China slowly disintegrate into national humiliation as wars were lost and humiliating treaties were signed.

\section{Flaws within the Qing Imperial Administration}

\subsection{Corruption}

Corruption was perhaps the most characteristic attribute of the waning days of the Qing Dynasty. Many members of the ruling scholar-gentry class often failed to carry out their duties properly, and frequently avoided reporting truthfully to the court about regional issues, and evaded contributing financially to national war efforts and policy initiatives. Officials and eunuchs bought and sold positions and promotions, accepted bribes, and frequently pocketed sums of money intended for public projects. In many cases, they prevented the allocation of public funds for genuine utilitarian purposes, believing such expenses to be profligate.

Corruption on the part of officials, eunuchs, and the imperial family would leave the Qing financially debilitated and unable to appropriate funds for public affairs. As capital became increasingly concentrated in private hands, the Qing state would suffer from a lack of adequate finances in administering its daily duties and interacting with the West.

\subsection{Cixi and the Overthrow of Patriarchy}

At all times and in all over the world, patriarchy has always held sway in human society, especially in the political arena where male politicians make up an overwhelmingly majority. Their female counterparts, on the contrary, have only turned into a handful of great politicians. However, one note is of importance that patriarchy is not necessarily equal to absolute dominion over female at every political level. In China, the power of morality is never inferior to that of patriarchy. There is no lack of precedents that female played a dominant part in the patriarchal society. Although females were subject to wifely submission and virtue, they enjoyed treatment with filial piety from their offspring demanded by ethical codes, and had enormous authority over their sons. Filial piety and loyalty are key values in Chinese traditional morality, and result in sons' absolute obedience to their mothers. Therefore, latent challenges from female may even overthrow patriarchy. From empress dowagers to ordinary women, female tried to seize power and establish themselves in the court or at home through their moral authority, inventing loopholes in the patriarchal structure. In palace politics, such ambition manifests itself best in the autocracy of empresses or empress dowagers.

From the succession of Emperor Tongzhi in 1862 to the demise of Qing Empire in 1911, power in Qing court had been held in female hands. During the twilight and eventful years of the late Qing Dynasty, Manchu women, from Empress Dowager Cixi to Empress Dowager Longyu, seized authority and exerted full control of political 
and military affairs, making the emperor a mere figurehead. The "ancestral rule" of the Qing Dynasty that female have no access to politics became nothing but a dead letter.

After the death of the Eastern Empress Dowager Ci'an, the imperial court, supposedly under the tutelage of the Kuang-Hsü Emperor, gradually shifted into the hands of the Western Empress Dowager Cixi. From thereon, court policy and authority would be subject to the whims and fancies of Cixi and her entourage of eunuchs. The court was transformed from an institution of scholar-officials and the Emperor who competently administered empire to a den of corruption that fuelled the personal and often conflicting objectives of both Cixi and the eunuchs.

A culture of corruption and misconduct rocked the Qing state to the core in its twilight years. Officials were no longer devoted to proper management of the Empire, bribery and corruption were widespread, and the monopolization of power by Cixi and the eunuchs spelt out a further deterioration of the political climate at the hands of self-interest.

\section{Conclusion}

The Self-Strengthening Movement in late Qing Dynasty, born of Chinese ethnocentrism, would ultimately be marred by such thought itself. Its goals of expanding Western technology, industry, and education to China would be seen as unnecessary and harmful to traditional Chinese society and culture. Its activities would be terminated at once if traditional Chinese practice were to be threatened. Its proponents would be denounced as deluded and misled. Conservatism and traditionalism in the Qing were caused in large part by the instability and numerical disadvantage of the Manchu court vis à vis the Han majority. Therefore, the primary cause to the failure of the reform lies in the intermediateness - lack of firm support from the supreme power system as well as the strong Chinese traditional culture.

Meanwhile, no powerful individual would come to champion the Movement in its undertakings. No grand councillors, grand secretary, eunuch, imperial prince, member of the royal family and not even the Emperor himself would show a strong commitment to the ideals and goals envisioned by the Self-strengthening Movement. The Self-strengthening Movement was thus limited to purely regional activities, none able to bring about substantial long-term benefits for the Qing.

Corruption and dysfunction by scholar-officials, institutional disorder, and the monopolization of power in the hands of the Empress Dowager Cixi and eunuchs would also spell out troubles for the reform. The Empire was prevented from functioning in a utilitarian manner. Instead, it was bogged down by self-interest and greed, its administrative tasks neglected, resulting in the haphazard and disjointed implementation of reform activities.

The Self-Strengthening Movement and its supporters envisioned a reborn China, a China that could interact with the West on its own terms. Yet, rather than envisioning a China that would adapt to a new world order as one among many sovereign states, the reformists envisioned a China that would return to its former position in the world as a hegemon, with all other foreign entities mere vassals and "barbarians". Through the emulation of the West and the adoption of Western ways, the Qing hoped to one day take up again this role. Such a hope never manifested itself. The Qing Empire would succumb to foreign conflicts, internal rebellions, famines, Han nationalism, and foreign spheres of interest infringing on its sovereignty. Whether or not the Self-strengthening Movement could ever have saved the Qing as an entity, the Qing's inability to adapt and assimilate itself into a new world order was both a cause of the Dynasty's demise and a result of its conservative mindset. The Self-strengthening Movement was certainly a victim of such a mindset.

After the collapse of the Qing in 1911, China would transit through many shifts in political and economic philosophies in an attempt to become a stronger state, from Confucianism to Republicanism and from Capitalism to Communism. Nearly a hundred years after the end of the Self-strengthening Movement, China would begin to rise again as a major economic and political power. Such would be the result of a radical change in mindset, although this time, it would be from China's willingness to set aside its communist dogma and adopt market-style economic policies. While China's past and culture are still deeply imbedded within its national conscience, its society and technological knowledge have transformed and facilitated its smooth integration into the global age.

\section{References}

Chu, S. C. (1965). Reformer in Modern China, Chang Chien, 1853-1926. New York and London: Columbia University Press.

Elman, B. A. (2004). Naval Warfare and the Refraction of China's Self-Strengthening Reforms into Scientific and Technological Failure, 1865-1895. Modern Asian Studies, 38(02), 283-326. http://dx.doi.org/10.1017/ S0026749X04001088 
Gasster, M. (1972). China's Struggle to Modernize (2nd ed.). New York: A.A. Knopf.

Kwong, L. S. (1984). A Mosaic of the Hundred Days: Personalities, Politics, and Ideas of 1898 (No. 112). Harvard Univ Asia Center.

Sun, L. Z. (2011). Late Qing China: Suffer Beating With Highest GDP. China Invention \& Patent, $1,54$. http://dx.doi.org/10.3969/j.issn.1672-6081.2011.01.016

\section{Copyrights}

Copyright for this article is retained by the author(s), with first publication rights granted to the journal.

This is an open-access article distributed under the terms and conditions of the Creative Commons Attribution license (http://creativecommons.org/licenses/by/4.0/). 